\title{
Effects of Mulching Tolerance Plant Straw on Phosphorus and Potassium Uptakes of Cyphomandra betacea Seedlings under Cadmium Stress
}

\author{
Piao Liu ${ }^{1, a}$, Huashan Lian²,b ${ }^{2, \text { Hongyan } \mathrm{Li}^{1, \mathrm{c}} \text { and Lijin Lin }}{ }^{1, \mathrm{~d}^{*}}$ \\ ${ }^{1}$ Institute of Pomology and Olericulture, Sichuan Agricultural University, Chengdu, Sichuan, China \\ ${ }^{2}$ Department of Landscape Gardening, Chendu Agricultural College, Chengdu, Sichuan, China \\ aliufei569@qq.com, b49939450@qq.com, c1432350417@qq.com, dllj800924@qq.com \\ ${ }^{*}$ Corresponding author. Piao Liu and Huashan Lian contributed equally to this work.
}

\begin{abstract}
Keywords: Cyphomandra betacea; Tolerant plant straw; Phosphorus; Potassium; Cadmium stress Abstract: A pot experiments were conducted to study the effect of mulching tolerance plant straw on phosphorus and potassium uptakes of Cyphomandra betacea seedlings under cadmium $(\mathrm{Cd})$ stress, four tolerance plants (Digitaria sanguinalis, Clinopodium confine, Plantago asiatica, Ranunculus sieboldii) straw were used as materials to mulch on the surface of Cd-contaminated soil and planted $C$. betacea seedlings. Cd-contaminated soil-mulched tolerant plant straw had effect on the contents of phosphorus and potassium in C. betacea seedling plants. Except for the P. asiatica straw mulching treatment, the contents in phosphorus and potassium in the roots of $C$. betacea seedlings treated with $D$. sanguinalis straw, $R$. sieboldii, and $C$. confine straw were significantly higher than those without soil-resistant straw. The contents of phosphorus and potassium in shoots of $C$. betacea seedlings were higher than those of control after mulching four tolerant plant straw, indicating that mulching tolerant plant straw promoted the translocation of phosphorus and potassium to the shoots of $C$. betacea seedlings. This experiment showed that compared with the $P$. asiatica straw, the straw mulched with $D$. sanguinalis straw, the $C$. confine straw, and the $R$. sieboldii straw were more beneficial to the uptake of tolerant in $\mathrm{Cd}$-contaminated soil by $C$. betacea seedlings.
\end{abstract}

\section{Introduction}

Cadmium (Cd) is one of the heavy metal elements harmful to plant growth and human health [1]. In recent years, the current status of cadmium pollution in China has become increasingly serious [2-3]. The Cyphomandra betacea is a fruit tree with commercial exploitation value of Solanaceae, and it is a fruit tree integrating flower, fruit and food, mainly in Southwest China [4]. Phosphorus and potassium are among the various nutrients needed in plants [5]. Straw mulching is a commonly used method of water retention and fertilization in agricultural practices [6]. It mainly releases organic matter, trace elements and other substances during the process of straw decomposing, improves soil physical and chemical properties, increases soil organic matter content, and then improves soil fertility and soil texture, which increases the yield and quality of crop [7]. This experiment used four tolerance plants (Digitaria sanguinalis [8], Clinopodium confine, Plantago asiatica and Ranunculus sieboldii [9]) straw mulch on the surface of Cd-contaminated soil and planted $C$. betacea seedlings, and the effect of mulching tolerance plant straw on phosphorus and potassium uptakes of $C$. betacea seedlings under cadmium $(\mathrm{Cd})$ stress.

\section{Materials and Methods}

Materials Collection. The shoots of four tolerance plants (D. sanguinalis, $C$. confine, $P$. asiatica and $R$. sieboldii) and soil were collected from the farmland of Ya'an Campus of Sichuan Agricultural University (not polluted by $\mathrm{Cd}$ ) in June, 2014. And fixed all plants at $110^{\circ} \mathrm{C}$ for 15 minutes and dried at $80^{\circ} \mathrm{C}$ until they were weighed after washing them with deionized water. Then cut into small pieces of less than $1 \mathrm{~cm}$ by scissors and stored. The seeds of $C$. betacea were collected from three-years of fruitful $C$. betacea from the Ya'an Campus of Sichuan Agricultural 
University in October 2013. And the seeds of C. betacea were sowed in the sand plate in June 2014.

Experimental Design. The experiment was conducted in farm of Ya'an Campus of Sichuan Agricultural University. In June 2014, the unpolluted soil was air-dried and passed through a 5-mm sieve. $3 \mathrm{~kg}$ air-dried soil was weighed into each plastic pot $(15 \mathrm{~cm}$ high, $18 \mathrm{~cm}$ in diameter), soaking uniformly $\mathrm{CdCl}_{2} \cdot 2.5 \mathrm{H}_{2} \mathrm{O}$ by $10 \mathrm{mg} / \mathrm{kg}$ and balanced for 4 weeks. In July 2014, the straws of four accumulator plants were separately mulched in Cd-contaminated soil surface. Coverage was $6 \mathrm{~g}$ per pot and the water was kept moist and equilibrated for one week. Then, the same growth $C$. betacea with the four real leaves were transplanted into the pots. Two plants were planted in each pot. Five replicates per treatment and all pots were watered each day to keep the soil moisture about $80 \%$. The distance between pots was $15 \mathrm{~cm}$, and the pot position exchanged aperiodically to weaken the impact of the marginal effects. After 40 days, all $C$. betacea seedlings were harvested and divided, fixed all plants at $110^{\circ} \mathrm{C}$ for 15 minutes and dried at $80^{\circ} \mathrm{C}$ until they were weighed after washing them with deionized water. The total phosphorus content of $C$. betacea seedlings were determined by molybdenum antimony colorimetric method [10]. The total potassium content of $C$. betacea seedlings were determined by flame spectrophotometer [10].

Statistical Analyses. Statistical analyses were conducted using statistical software of SPSS 17.0. Data were analyzed by one-way ANOVA with least significant difference at 5\% confidence level.

\section{Results and Discussion}

Phosphorus Contents in $\boldsymbol{C}$. betacea Seedlings. The total phosphorus content in $C$. betacea seedling plants is shown in Table 1. After mulching tolerant plant straw, the total phosphorus content in the roots of $C$. betacea seedlings was in the following order: D. sanguinalis straw $>R$. sieboldii straw $>C$. confine straw $>$ control $>P$. asiatica straw, where the soil mulched $D$. sanguinalis straw treatment, $R$. sieboldii straw treatment and $C$. confine straw treatment The content of total phosphorus in the roots of the treatment and adjacent to the cabbage and straw was increased by $132.70 \%(P<0.05), 96.58 \%(P<0.05)$ and $11.03 \%(P>0.05)$, respectively. The total phosphorus content in the roots was not significantly different from the control. Excluding the $P$. asiatica straw and $R$. sieboldii straw, the content of total phosphorus in the stems of $C$. betacea seedlings was significantly lower than that of control. The rest of the treatments were significantly higher than the control. The order of the total phosphorus content was: C. confine straw $>D$. sanguinalis straw $>$ control $>P$. asiatica straw $>R$. sieboldii straw. The order of total phosphorus content in leaves and shoots of plant $C$. betacea seedlings were as follows: $D$. sanguinalis straw $>C$. confine straw $>R$. sieboldii straw $>P$. asiatica straw $>$ control, the total phosphorus content in shoots of $C$. betacea seedlings that were mulched with $D$. sanguinalis straw, $C$. confine straw, $R$. sieboldii and straw and $P$. asiatica straw increased by $121.01 \%(P<0.05), 100.00 \%(P<0.05)$, 40.62\% $(P<0.05)$, and 3.08\% $(P>0.05)$, respectively, compared with the control.

Table 1 Effects of mulching tolerant plant straw on total phosphorus content in C. beracea seedlings

\begin{tabular}{|c|c|c|c|c|}
\hline Tolerant plant straw & $\begin{array}{c}\text { Root } \\
(\mathrm{g} / \mathrm{kg})\end{array}$ & $\begin{array}{c}\text { Stem } \\
(\mathrm{g} / \mathrm{kg})\end{array}$ & $\begin{array}{c}\text { Leaf } \\
(\mathrm{g} / \mathrm{kg})\end{array}$ & $\begin{array}{c}\text { Shoot } \\
(\mathrm{g} / \mathrm{kg})\end{array}$ \\
\hline Control & $0.263 \pm 0.001 \mathrm{~cd}$ & $0.273 \pm 0.002 \mathrm{c}$ & $0.396 \pm 0.009 \mathrm{de}$ & $0.357 \pm 0.002 \mathrm{c}$ \\
\hline D. sanguinalis & $0.612 \pm 0.011 \mathrm{a}$ & $0.394 \pm 0.007 \mathrm{~b}$ & $0.988 \pm 0.044 \mathrm{a}$ & $0.789 \pm 0.044 \mathrm{a}$ \\
\hline C. confine & $0.292 \pm 0.002 \mathrm{c}$ & $0.649 \pm 0.012 \mathrm{a}$ & $0.747 \pm 0.025 \mathrm{~b}$ & $0.714 \pm 0.031 \mathrm{a}$ \\
\hline P. asiatica & $0.233 \pm 0.001 \mathrm{~d}$ & $0.238 \pm 0.002 \mathrm{~d}$ & $0.435 \pm 0.013 \mathrm{~d}$ & $0.368 \pm 0.001 \mathrm{c}$ \\
\hline R. sieboldii & $0.517 \pm 0.002 \mathrm{~b}$ & $0.173 \pm 0.001 \mathrm{e}$ & $0.656 \pm 0.035 \mathrm{c}$ & $0.502 \pm 0.012 \mathrm{~b}$ \\
\hline
\end{tabular}

Note: Different letters indicate significant difference at $5 \%$ level among different treatments.

Potassium Contents in $C$. betacea Seedlings. The effects of tolerance plant straw-mulched $C$. betacea seedlings on their total potassium content were shown in Table 2. After the soil mulched the resistant plant straw, the total potassium content were not significantly different except for the $P$. asiatica straw treatment compared with the control. The rest of the treatments were significantly 
higher than the the control. The order of their size was as follows: D. sanguinalis straw $>R$. sieboldii straw $>C$. confines straw $>$ control $>P$. asiatica straw. The total potassium content in roots of $C$. betacea seedlings mulched by straw of $D$. sanguinalis, $R$. sieboldii and $C$. confines was increased by $122.70 \%(P<0.05), 106.57 \%(P<0.05)$, and $33.45 \%(P<0.05)$ compared with the control. After the soil was mulched with tolerant plant straw, the total potassium content in stems, leaves and shoots of $C$. betacea seedlings was higher than that of control. The order of the total potassium content was as follows: $D$. sanguinalis straw $>R$. sieboldii straw $>C$. confines straw $>P$. asiatica straw $>$ control. These results showed that mulching tolerant plant straw promoted the transfer of potassium to the shoot of $C$. betacea seedlings. The total potassium content in shoots of $C$. betacea seedlings with $D$. sanguinalis straw, $C$. confine straw, $P$. asiatica straw and $R$. sieboldii straw were 5.37 times $(P<0.05)$ and 2.60 times $(P<0.05), 2.59$ times $(P<0.05)$ and 2.07 times $(P$ $<0.05)$ than control. These results showed that mulching tolerant plant straw promoted the transfer of potassium to the shoot of $C$. betacea seedlings.

Table 2 Effects of mulching tolerant plant straw on total potassium content in C. beracea seedlings

\begin{tabular}{|c|c|c|c|c|}
\hline Tolerant plant straw & $\begin{array}{c}\text { Root } \\
(\mathrm{g} / \mathrm{kg})\end{array}$ & $\begin{array}{c}\text { Stem } \\
(\mathrm{g} / \mathrm{kg})\end{array}$ & $\begin{array}{c}\text { Leaf } \\
(\mathrm{g} / \mathrm{kg})\end{array}$ & $\begin{array}{c}\text { Shoot } \\
(\mathrm{g} / \mathrm{kg})\end{array}$ \\
\hline Control & $27.71 \pm 0.82 \mathrm{~d}$ & $20.83 \pm 1.14 \mathrm{~d}$ & $13.56 \pm 0.64 \mathrm{~d}$ & $15.85 \pm 0.92 \mathrm{~d}$ \\
\hline D. sanguinalis & $61.71 \pm 3.32 \mathrm{a}$ & $71.52 \pm 3.68 \mathrm{a}$ & $91.95 \pm 4.65 \mathrm{a}$ & $85.10 \pm 2.64 \mathrm{a}$ \\
\hline C. confine & $36.98 \pm 1.33 \mathrm{c}$ & $39.95 \pm 1.45 \mathrm{~b}$ & $41.62 \pm 2.99 \mathrm{~b}$ & $41.07 \pm 1.17 \mathrm{~b}$ \\
\hline P. asiatica & $27.06 \pm 1.01 \mathrm{~d}$ & $30.05 \pm 1.79 \mathrm{c}$ & $34.18 \pm 0.51 \mathrm{c}$ & $32.78 \pm 1.76 \mathrm{c}$ \\
\hline R. sieboldii & $57.24 \pm 2.93 \mathrm{~b}$ & $40.49 \pm 2.11 \mathrm{~b}$ & $41.63 \pm 1.82 \mathrm{~b}$ & $41.26 \pm 1.35 \mathrm{~b}$ \\
\hline
\end{tabular}

Note: Different letters indicate significant difference at $5 \%$ level among different treatments.

\section{Conclusions}

Cd-contaminated soil-mulched tolerant plant straw had effect on the contents of phosphorus and potassium in $C$. betacea seedling plants. Except for the $P$. asiatica straw mulching treatment, the contents in phosphorus and potassium in the roots of $C$. betacea seedlings treated with $D$. sanguinalis straw, $R$. sieboldii, and $C$. confine straw were significantly higher than those without soil-resistant straw. The contents of phosphorus and potassium in shoots of $C$. betacea seedlings were higher than those of control after mulching four tolerant plant straw, indicating that mulching tolerant plant straw promoted the translocation of phosphorus and potassium to the shoots of $C$. betacea seedlings. This experiment showed that compared with the $P$. asiatica straw, the straw mulched with $D$. sanguinalis straw, the $C$. confine straw, and the $R$. sieboldii straw were more beneficial to the uptake of tolerant in Cd-contaminated soil by $C$. betacea seedlings.

\section{Acknowledgements}

This work was financially supported by the Application Infrastructure Project of Science and Technology Department of Sichuan Province (2016JY0258).

\section{References}

[1] L. Li, J. B. Zhang and W. N. Huang: Journal of Ecology Vol. 20 (2000), p. 514.

[2] H. L. Li, G. H. Xiao and Q. S. Liu: Journal of Southern Agriculture Vol. 45 (2014), p. 1986.

[3] L. Xu, M. Zhang and Y. Hao: Journal of Nanjing Normal University Vol. 34 (2011), p. 102.

[4] J. A. M. V. D. Mey, G. A. M. V. Hasselt and D. E. M. Elsevier: Genetica Vol. 40 (1969), p. 413.

[5] H. Zhu, J. Wu, D. Huang, Q. Zhu, S. Liu, Y. Su, W. Wei, J. K. Syers and Y. Li: Plant and Soil Vol. 33 (2010), p. 427. 
[6] B. Gong, S. Bloszies, X. Li, M. Wei, F. Yang, Q. Shi and X. Wang: Scientia Horticulturae Vol. 161 (2013), p. 49.

[7] P. J. A. Asten, P. M. Bodegom, L. M. Mulder and M. J. Kropff: Nutrient Cycling in Agroecosystems Vol. 72 (2005), p. 255.

[8] E. A. Ewais: Biologia Plantarum Vol. 39 (1997), p. 403.

[9] L. Lin, Q. Jin, Y. Liu, B. Ning, M. Liao and L. Luo: Environmental Toxicology and Chemistry Vol. 33 (2014), p. 2422.

[10]S.D. Bao: Agrochemical Soil Analysis (3rd edition, China Agriculture Press, Beijing, China 2000). 